\title{
ANALISIS PELATIHAN MARKETPLACE BAGI PELAKU USAHA KUE DI MASA PANDEMIK COVID-19 DI DESA JATIRAGAS
}

\author{
Enjang Suherman ${ }^{1}$, Rika Uswatun Hasanah ${ }^{2}$ \\ enjangsuherman@ubpkarawang.ac.id dan Mn17.rikahasanah@mhs.ubpkarawang.ac.id,
}

\begin{abstract}
Abstrak
Pemanfaatan internet menjadi andalan dalam melakukan pemasaran online melalui media sosial, jasa pengiklanan, toko online, dan masih banyak lainnya. Terutama dimasa pandemik seperti ini dimana pembatasan sosial diberlakukan untuk memutus rantai covid-19 sehingga aktivitas jual beli secara online melalui marketplace dapat memudahkan dalam bertransaksi. Pemasaran online merupakan pendukung sebuah konsep pemasaran modern. Konsep tersebut berupa segala macam bentuk promosi dan penjualan produk atau jasa melalui internet. Tujuan pelaksanaan pelatihan kegiatan untuk memberikan ide, dan gagasan sebagai upaya meningkatkan pemasaran dengan metode pemasaran online melalui marketplace.

Metode yang dilakukan penelitian ini adalah metode deskriptif. Teknik pengumpulan data melalui wawancara dan observasi pada saat kegiatan tersebut dengan berdiskusi dengan perwakilan perangkat desa Jatiragas dan tim KKN desa Jatiragas. Analisis penelitian ini menggunakan analisis deskriptif untuk memberikan gambaran secara umum atas pelaksanaan pelatihan marketplace bagi pelaku usaha keu di desa Jatiragas.

Hasil dan Pembahasan yaitu Desa Jatiragas memiliki potensi dari berbagai aspek, salah satunya adalah potensi ekonomi dalam pembuatan kue. Kurangnya pengetahuan pemanfaatan teknologi, pemasaran Kue dilakukan melalui word of mouth (dari mulut ke mulut) dan pemasaran melalui whatsapp, sehingga membuat cakupan pemasaran Kue belum mencakup luas. Untuk pengembangan pemasaran kue desa Jatiragas dapat dilakukan dengan menggunakan metode pemasaran online melalui pemanfaatan teknologi yakni dengan memanfaatkan e-commerce seperti marketplace pada aplikasi shopee, lazada, tokopedia, blibli, dan sebagainya sedangkan pelaksanaan pelatihan tersebut menggunakan metode diskusi dan metode peragaan atau contoh sehingga pelaku usaha dapat mengakses marketplace tersebut.
\end{abstract}

Kata Kunci : Analisis Pelatihan, dan marketplace, 


\section{Pendahuluan}

Desa Jatiragas merupakan desa yang terletak di sebelah timur kabupaten Karawang, lebih tepatnya di Kecamatan Jatisari. Jatiragas dikenal sebagai Desa yang mempunyai Potensi, potensi yang dimaksud ada tiga yaitu, Aspek Pendidikan, Keagamaan, dan Aspek Ekonomi. Berikut ini pengembangan potensi yang dimiliki oleh desa jatirgas :

1. Aspek Pendidikan

Dalam Aspek Pendidikan desa Jatiragas Merupakan salah satu desa yang lengkap, karena semua jenjang Pendidikan di desa Jatiragas ada dari tingkat TK, PAUD, Madrasah, SD, SMP, SMA dan bahkan Pesantren. Pendidikan yang paling dikenal di desa Jatiragas adalah banyak sekali Pesantren sehingga Masyarakat desa Jatiragas sangat kental dalam Keagamaannya.

2. Aspek Ekonomi

Dalam Aspek Ekonomi sepeti yang sudah saya jelaskan desa Jatiragas adalah desa yang mayoritas masyarakatnya membuat kue untuk dijual di desa dan di acara hajatan atau pesta

3. Aspek Agama

Seperti yang sudah dijelaskan pada aspek Pendidikan, Keagamaan di desa Jatiragas sangat kental karena di desa tersebut terdapat beberapa Pesantren. Banyak masyarakat yang menempuh Pendidikan di pesantren desa Jatiragas, karena pesantren desa Jatiragas memiliki kualitas Pendidikan yang baik.

Desa Jatiragas memiliki potensi dari berbagai aspek, namun yang menjadi perhatian penulis adalah potensi ekonomi dalam pembuatan Kue yang diproduksi oleh masyararakat desa Jatiragas. Kue ini produksi kue rumahan keluarga, dan kue yang diproduksi bermacammacam , yakni kue rendang, bibika, wingka, kue lapis, kue ali, bolu, lemper, dan masih banyak lainnya.

Dusun yang membuat Kue di Desa Jatiragas, terletak di Dusun 1 Kampung Lembur Gede Rw 02, dan terdapat 15 rumah yang membuat Kue. Setiap pembuatan Kue bisa mencapai 500 lebih dari per macam kue nya, pembuatan Kue di buat ketika ada pemesanan dan biasanya memiliki stock Kue untuk pembeli yang datang kerumah.

Sistem penjualan Kue dilakukan dengan menyuplai ke pasar jatiwangi dan ketika ada pesanan acara saja, sedangkan untuk pemasaran nya dilakukan melalui word of mouth (dari mulut ke mulut) dan pemasaran melalui whatsapp. Kurangnya pengetahuan pemanfaatan teknologi seperti pembuatan toko online pada masyarakat, membuat cakupan pemasaran Kue belum mencakup luas. Sehingga diperlukan sosialisasi atau pelatihan dengan dibantu oleh tim 
KKN sebagai pengabdian kepada masyarakat untuk memperluas pemasaran produk secara online melalui marketplace.

\section{Landasan Teori}

Menurut William J Stanton dalam (Basu Swastha \& Irawan, 2003) Pemasaran adalah suatu sistem keseluruhan dari kegiatan-kegiatan usaha yang ditujukan untuk merencanakan, menentukan harga, mempromosikan dan mendistribusikan barang dan jasa yang dapat memuaskan kebutuhan, baik kepada pembeli maupun pembeli potensial. Menurut (Tjiptono, 2002) berpendapat bahwa strategi pemasaran merupakan alat fundamental yang direncanakan untuk mencapai perusahaan dengan mengembangkan keunggulan bersaing yang berkesinambungan melalui pasar yang dimasuki dan program pemasaran yang digunakan untuk melayani pasar sasaran tersebut.

Pemasaran online merupakan pendukung sebuah konsep pemasaran modern. Konsep tersebut berupa segala macam bentuk promosi dan penjualan produk atau jasa melalui internet. Pemanfaatan internet menjadi andalan dalam melakukan pemasaran online melalui media sosial, jasa pengiklanan, toko online, dan masih banyak lainnya. Jadi pemasaran online adalah usaha yang dialakukan untuk mempromosikan produk atau jasa dengan menggunakn internet.

Perkembangan teknologi saat ini merupakan suatu kebutuhan yang harus dimiliki untuk meningkatkan pelayanan pada suatu organisasi. Pemanfaatan teknologi untuk membuat toko online melalui E-commerce sangat diperlukan untuk mempermudah dalam melakukan aktivitas jual beli dan memperluas pemasaran produk, agar produk dapat dikenal oleh masyrakat luas sehingga dapat meningkatkan penjualan. Peran e-commerce menunjang berkembangnya kegiatan perdagangan secara online melalui melalui keputusan pembelian yang dilakukan oleh konsumen. (Handayani, 2017). Marketplace didefinisikan sebagai website atau aplikasi online dangan fasilitas proses jual beli dari berbagai toko . Konsep marketplace kurang lebih seperti pasar tradisional, marketplace menyediakan tempat untuk penjual yang ingin berjualan produknya dan membantu bertemunya dengan pelanggan dan di fasilitasi transaksi dengan lebih mudah dan efesien (Nathasya, 2018).

Penggunaan metode pemasaran online melalui marketplace, memiliki kekurangan dan kelebihan tersendiri. Kelebihan dari pemasaran online yaitu memperluas cakupan wilayah yang masih dapat dijangkau oleh akses internet, mengurangi biaya sewa, fleksibilitas waktu dan lainnya. Sedangkan untuk kekurangan nya adalah teknik marketing yang cukup sulit 
dipahami oleh masyarakat awam, karena membutuhkan waktu untuk mempeljarinya dan kesabaran menghadapi kesabaran saat menghadapi konsumen.

Pelatihan adalah proses sistematis mengubah tingkah laku pegawai yang berkaitan dengan keahlian dan keterampilan dalam melaksanakan pekeraan saat ini.(Rivai dan Sagala. 2011). Sasaran pelatihan dapat dikategorikan dalam beberapa tipe tingkah laku yang diinginkan yaitu

1. Kategori Psikomotor, sasaran agar orang memiliki keterampilan fisik tertentu.

2. Kategori Apektif, sasaran agar orang memiliki sikap tertentu.

3. Kategori Kognitif, sasaran agar memiliki pengetahuan dan keterampilan berfikir.

Metode yang dipilih hendak disesuaikan dengan jenis pelatihan yang akan dilaksanakan dan yang dapat dikembangkan oleh suatu perusahaan. Diantaranya

1. On the job training, pelatihan dengan cara para pegawai ditempatkan dalam kondisi pekerjaan yang riil di bawah bimbingan dan supervisi dari pegawai yang berpengalaman.

2. Ceramah, pendekatan terkenal karena menawarkan sisi ekonomis dan material organisasi.

3. Simulasi, pelatihan yang menggunakan peraga sebagai simulasi atas suatu pekerajaan.

4. Peragaan, pelatihan ini dilakukan dengan cara peragaan tentang penjelasan tatacara mengerjakan suatu pekerjaan melalui contoh dan percobaan yang sedang didemonstrasikan.

\section{METODE}

Metode penelitian ini menggunakan metode deskriptif untuk memberikan suatu gambaran tertentu atas pelatihan yang dilakukan oleh tim KKN UBP Karawang kepada pelaku usaha mengenai pemasaran online marketplace.

Teknik pengumpulan data menggunakan wawancara, dan observasi pada saat pelaksanaan kegiatan pelatihan tersebut. Analisis penelitian ini menggunakan analisis deskriptif dengan tahapan pengumpulan data, reduksi data, penyajian data dan penarikan kesimpulan.

\section{Hasil dan Pembahasan}

Sasaran pelatihan kegiatan ini ditujukan untuk membantu masyarakat desa Jatiragas, terutama untuk masyarakat yang membuat Kue rumahan agar pemasaran nya dapat mencakup secara meluas dengan menggunakan marketplace shopee dan penjualannya dibantu oleh BUMDES. selain itu, tujuan dari kegiatan ini ditujukan untuk mengembangkan potensi - potensi yang ada di desa Jatiragas. 
Metode yang dilakukan adalah metode diskusi dan metode peragaan atau contoh dengan perwakilan perangkat desa Jatiragas dan tim KKN desa Jatiragas. Dalam upaya meningkatkan pemasaran Kue, penulis berdiskusi dengan perwakilan perangkat desa. Adapun data pendukung yang di dapat penulis dari artikel dan buku mengenai pembahasan mengenai pemasaran serta marketplace.

Pelaksanaan kegiatan dilakukan untuk memberikan penyuluhan dan pelatihan mengenai pengembangan pemasaran produk melalui Toko Online atau Marketplace. Berikut ini ada beberapa tahapan dalam memberikan penyuluhan dan pelatihan :

a. Tahap 1 : Mulai Kegiatan (Menyurvei dan berdiskusi dengan pengkat Desa)

Pada awal dimulai kegiatan dilakukan diskusi dengan perangkat desa secara virtual untuk memenuhi kebutuhan data yang diperlukan. Agar dapat dianalisis kebutuhan analisis fungsional dan non fungsional.

b. Tahap 2 : Perumusan Masalah

Pada tahapan ini menganalisis permasalahan yang terjadi di desa Jatiragas, penulis menganalisis permasalahan yang terdapat pada pembuatan Kue rumahan desa Jatiragas. Permasalahan nya terdapat pada kurangnya pengembangan pemasaran dan kurangnya pemahaman mengenai marketplace.

c. Tahap 3 : Memberikan sosialiasi dan pelatihan

Melakukan sosialisasi metode pemasaran melalui marketplace untuk mengembangkan pemasaran, dengan menjelaskan manfaat, kekurangan, dan tata cara penggunaan marketplace.

Pembuatan Kue diproduksi ketika ada pesanan dan membuat stock dirumah untuk pelanggan yang datang langsung kerumah. Sistem penjualan Kue di jual ke pasar, dan menerima pemesanan kue untuk acara. Sedangkan untuk pemasaran Kue dilakukan melalui postingan whatsaap dan dari mulu ke mulut. Dikarenakan kurangnya pengembangan pemasaran, Kue hanya menjangkau lingkungan sekitar.

Solusi untuk pengembangan pemasaran Kue desa Jatiragas dapat dilakukan dengan menggunakan metode pemasaran online melalui pemanfaatan teknologi, yakni dengan memanfaatkan e-commerce seperti marketplace pada aplikasi shopee, lazada, tokopedia, blibli, dan sebagainya. Di masa pandemik covid-19 seperti ini, penggunaan marketplace menjadi sangat meningkat, karena pembatasan sosial untuk memutus mata rantai covid-19 yang mengharuskan melakukan segala kegiatan dari rumah, seperti kegiatan belajar, pekerjaan, dan pembelanjaan. Oleh karena itu saat ini pemasaran online melalui marketplace sangat bermanfaat dan diperlukan untuk mencakup masyarakat luas dan meningkatkan 
penjualan. Berikut ini terdapat tata cara pembuatan akun toko marketplace pada halaman website shopee sebagai upaya metode pemasaran oline :

1. Buka website shopee pada browser dengan memasukan link https://shopee.co.id atau bisa juga dengan mendowloand aplikasi shopee pada playstore.

2. Setelah halaman atau aplikasi shopee terbuka, klik daftar seperti gambar di bawah ini

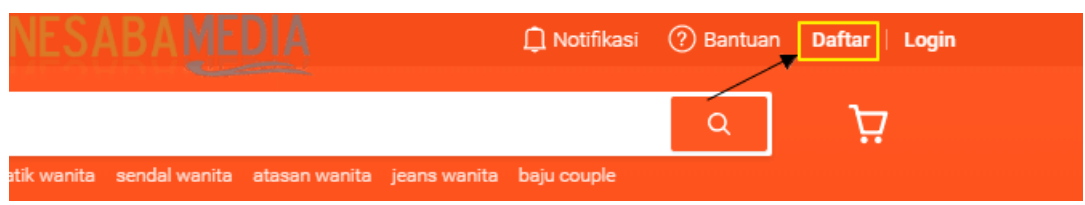

Sumber : Nesabamedia

3. Setelah itu, akan ada tampilan seperti ini

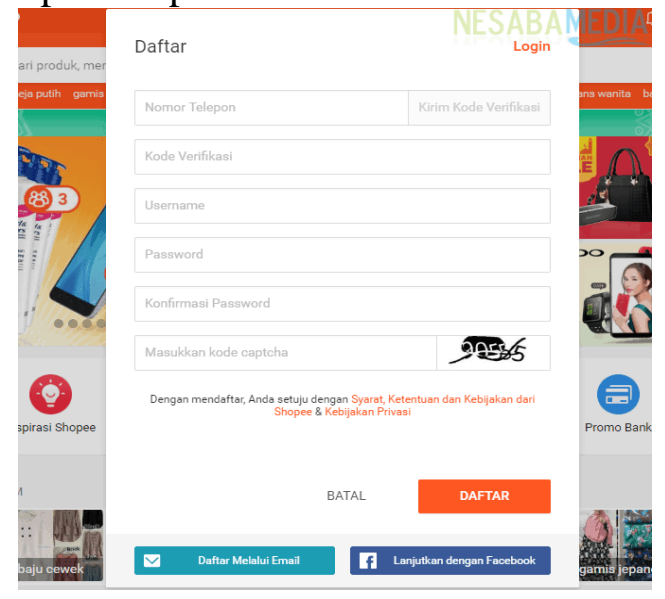

Sumber : Nesabamedia

Lalu silahkan diisi form untuk registrasi, berikut langkahnya :

a. Masukan nomor telepon lalu klok verifikasi. Anda akan mendapat kode verifikasi melalui SMS, kemudian masukkan kode verivikasi tersebur di koak Kode verifikasi.
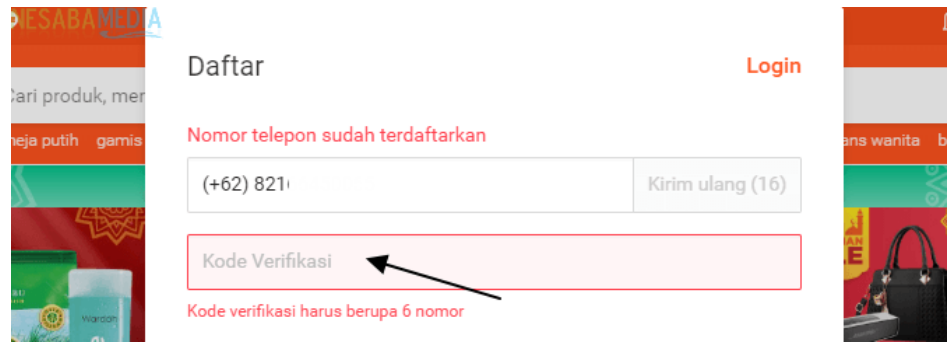

\section{Sumber : Nesabamedia}

b. Kemudian masukan username, password dan konfirmasi password.

c. Masukan kode captcha sesuai dengan gambar captcha di sebelahnya

d. Kemudian klik daftar

Untuk pendfataran akun selain dengan mengisi form, paendaftaran juga bisa mendaftar melalui facebook atau email. 
4. Jika sudah berhasil registrasi, kemudian klik jual

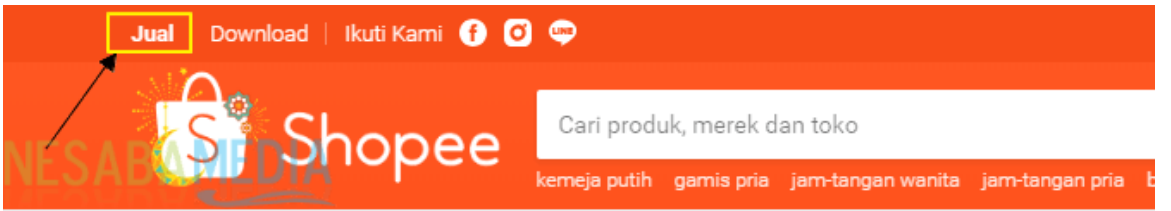

Sumber : Nesabamedia

5. Setelah klik jual, maka akan ada tampilan pilihan lalu klik pengaturan toko

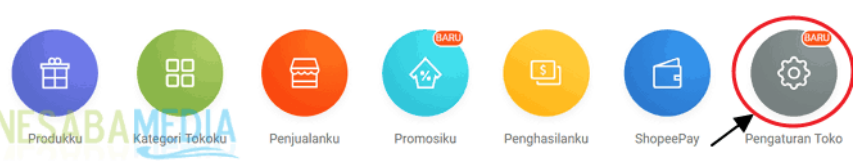

Sumber : Nesabamedia

6. Selanjutnya mengisi proil toko, isi dan lengkapi yang ditandai dengan kotak merah pada gambar dibawah ini, yang teridiri atas nama toko, deskripsi gambar, upload gambar/video, deskripsi toko,logo/foto toko, dan banner toko. Jika sudah diisi, kemudian klik simpan.
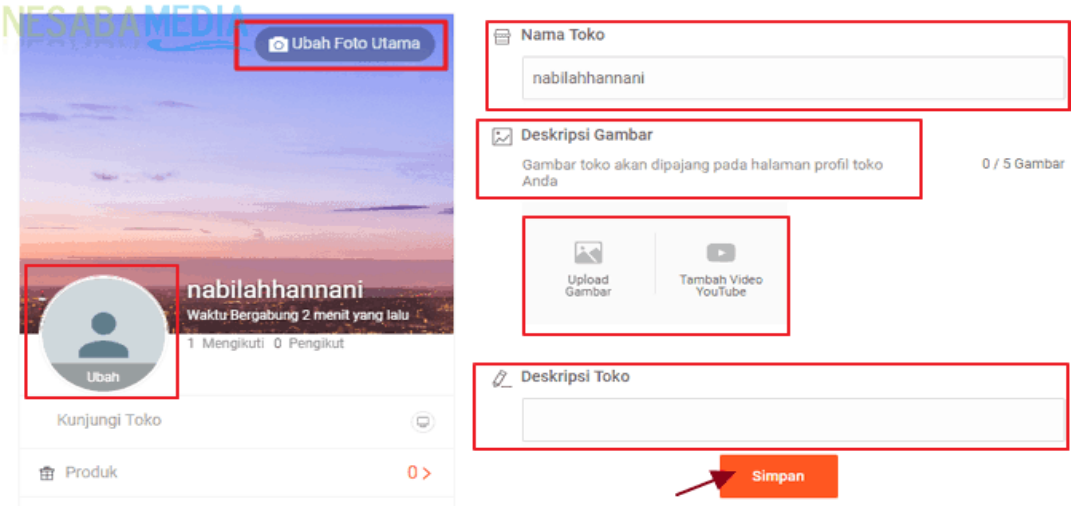

Sumber : Nesabamedia

7. Setelah itu, pilih Alamat saya untuk mengatur alamat toko.

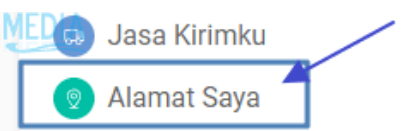

Sumber : Nesabamedia

8. Klik tombol + Tambah alamat baru

(2) Alamat Saya

Sumber : Nesabamedia 
9. Kemudian akan muncul tampilan form tambah alamat baru, isi kemudian lengkapi data tersebut lalu klik Simpan.

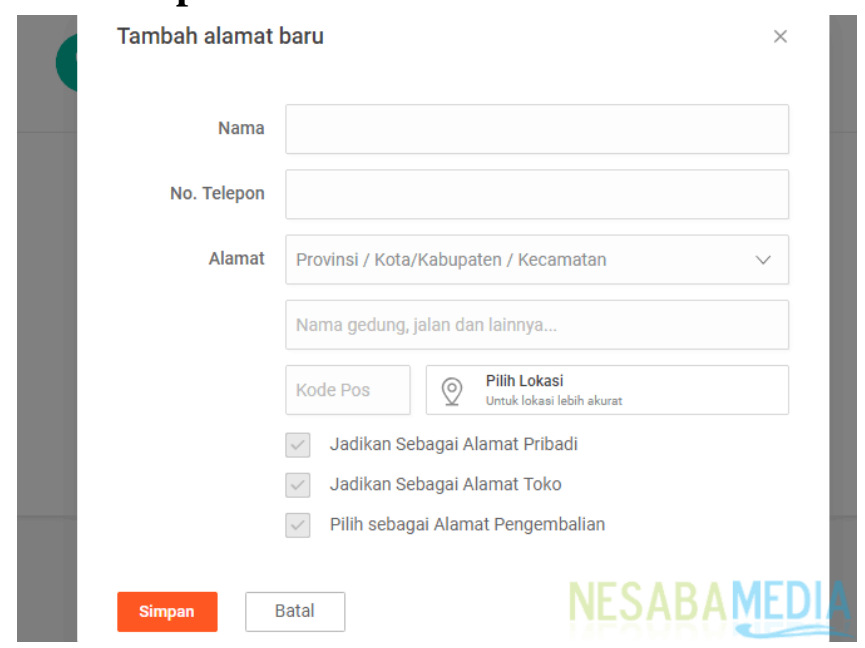

Sumber : Nesabamedia

10. Kemudian pilih Jasa kirimku

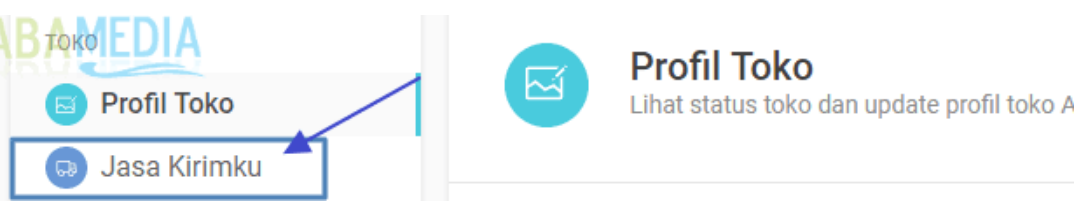

Sumber : Nesabamedia

11. Pilih jasa kirim toko dengan mengaktifkan tombol yang tersedia di samping masingmasing jasa kirim( jasa kirim aktif jika tombol sudah warna hijau)

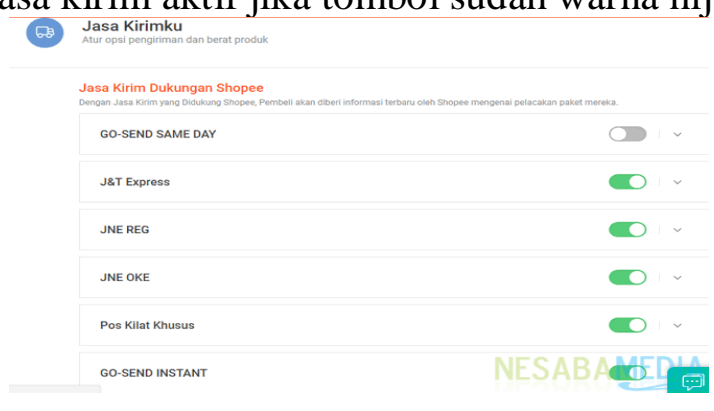

\section{Sumber : Nesabamedia}

Untuk metode pemasaran produk Kue pada marketplace, sebaiknya mengakftikan jasa kirim dengan sistem COD. Jika pengiriman dilakukan melalui ekspedisi, akan memerlukan waktu lebih lama untuk produk dapat diterima oleh konsumen. Karena produk Kue memiliki tingkat expired yang lebih cepat, perhatikan alamat pelanggan dan kecuali jika jasa kirim nya menggunakan fitur express yang tingkat penyampaian nya 1 hari 
12. Setelah memilih jasa kirim, kemudian mengatur rekening bank untuk melakukan transaksi pembayaran atau penerimaan uang penjualan di shopee dengan mengklik

\section{Kartu/Rekening Bank}

굴 Kartu / Rekening Bank

J\&T Express

\section{Sumber : Nesabamedia}

13. Untuk keamanan, masukan password shopee sebagai verifikasi. Kemudian klik Login

Untuk melindungi keamanan akun Anda, mohon masukkan password Shopee Anda untuk diverifikasi.

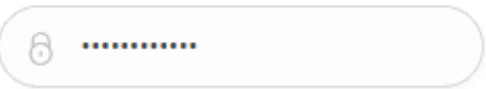

Batal

Sumber : Nesabamedia

14. Untuk menambahkan rekening bank pemilik toko, klik ikon tambah +

E Kartu / Rekening Bank Alur Rekening Bank Anda

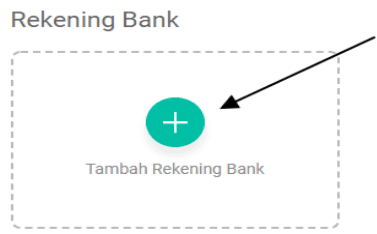

Sumber : Nesabamedia

15. Stelah itu, isi form dan lengkapi data. Kemudian klik Berikutnya

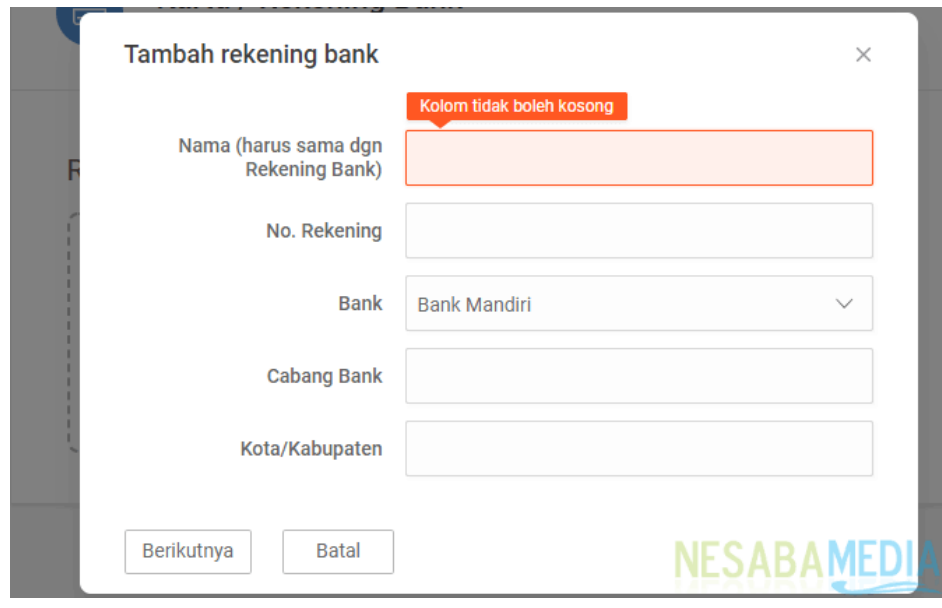

Sumber : Nesabamedia 
16. Setelah pengaturan pembuatan toko sudah selesai, diperlukan pengaturan lainnya

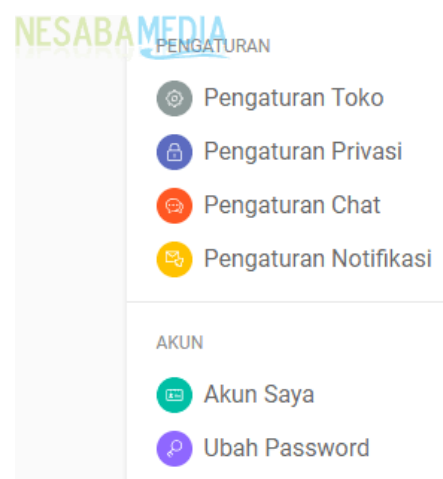

Sumber : Nesabamedia

17. Setelah pembuatan toko dan penyuntingan pengaturan selesai, maka langkah selanjutnya menambahkan produk pada toko dengan mengklik Produku

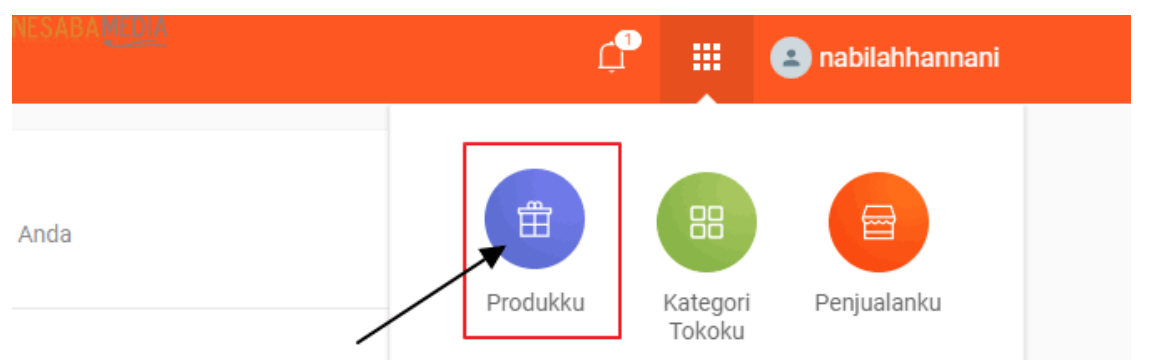

Sumber : Nesabamedia

18. Untuk menambahkan produk, klik ikon +

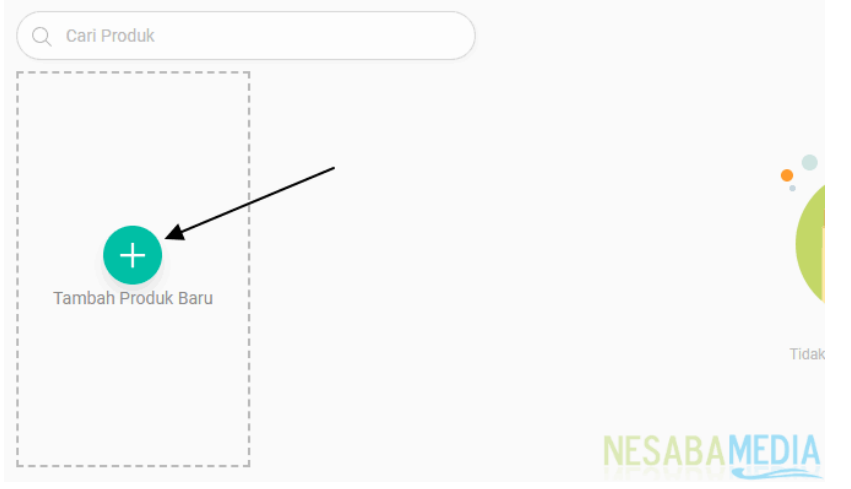

Sumber : Nesabamedia

19. Kemudian masukan pilihan gambar produk dengan mengklik tombol Pilih Gambar

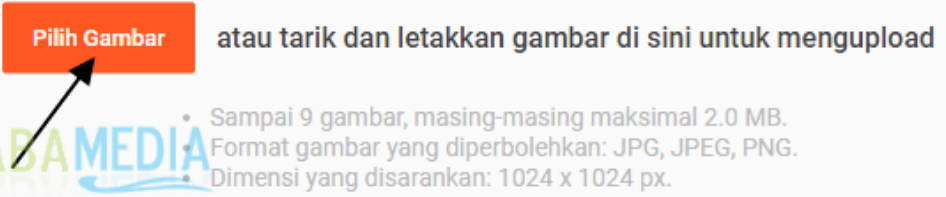

Sumber : Nesabamedia 
20. Setelah gambar berhasil diupload, kemudian isi form mengenai informasi produk seperti harga, jasa kirim, deskripsi dan sebagainya.kemudian klik Simpan

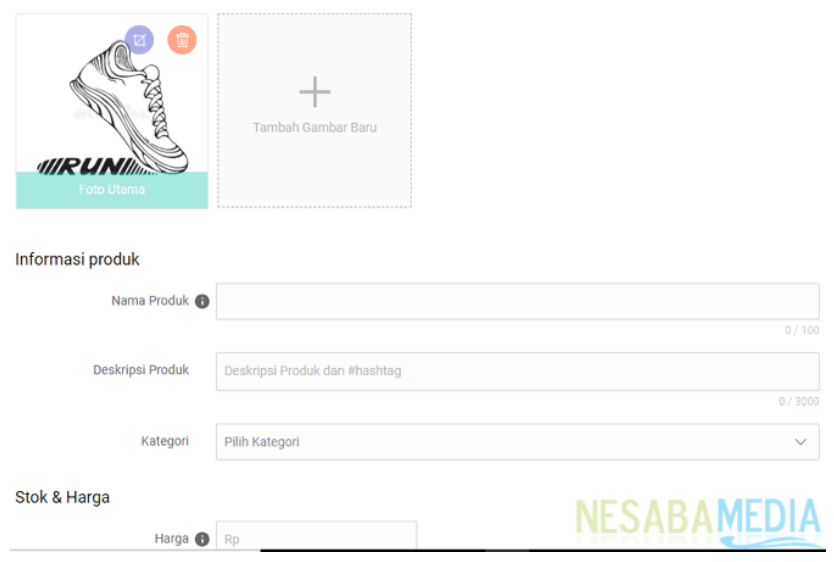

Sumber : Nesabamedia

21. Setelah disimpan, maka produk pertama sudah ditambahkan pada toko .

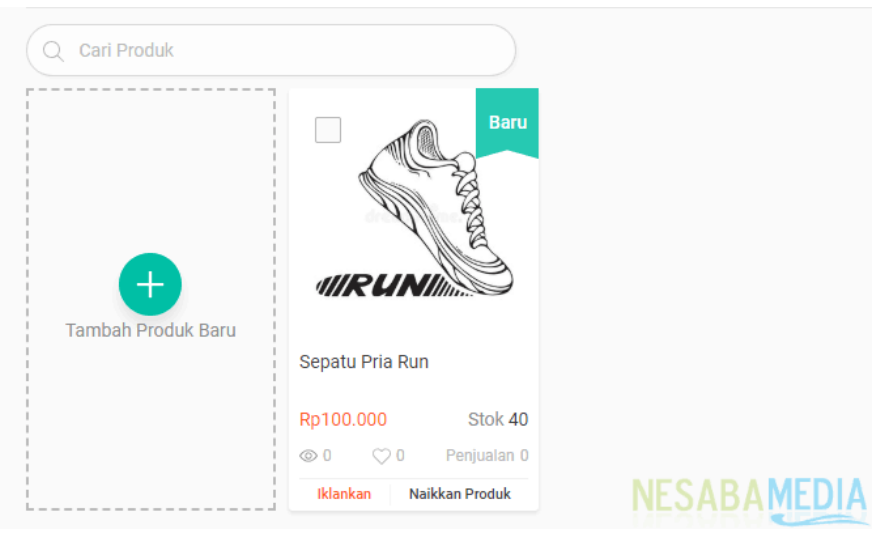

Sumber : Nesabamedia

22. Tampilan produk pada halaman utama profile toko

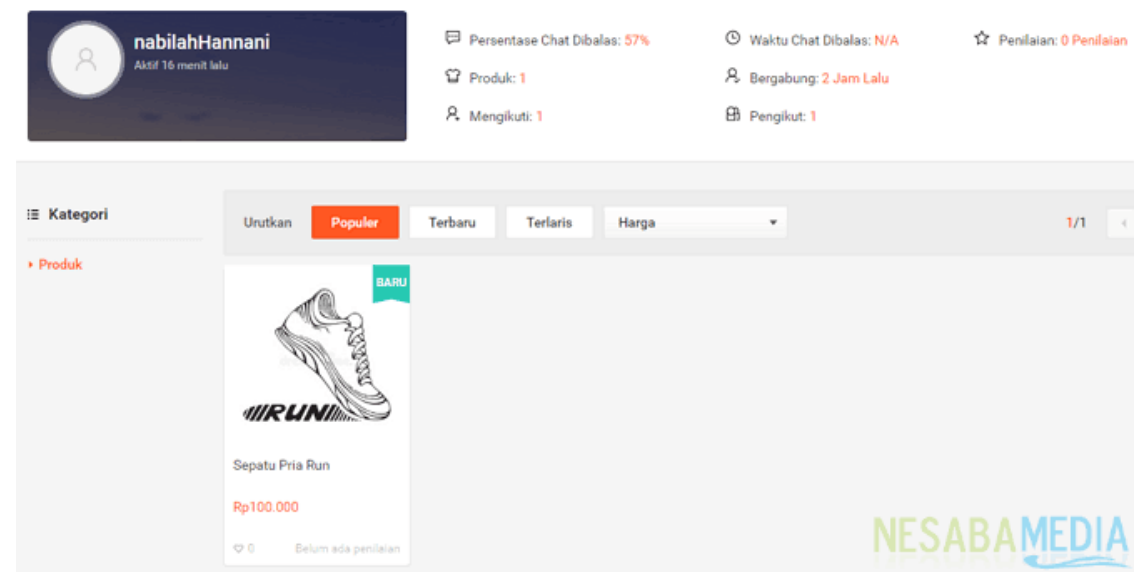

\section{Sumber : Nesabamedia}

Simulasi atas peragaan contoh tersebut para pelaku usaha kue dapat mencoba dan dapat mendaftarkan diri menjadi pelaku usaha online, sehingga pangsa pasarnya dapat lebih luas dan menyebar. Namun sebagai terdapat temuan mengenai pelaksanaan pelatihan marketplace 
tersebut, yaitu produk yang akan dipasarkan masih tergolong produk cepat basi atau kadaluarsa. Seperti kue basa. Kekuatan kue basah hanya sekitar 2-3 hari, sedangkan pengiriman barang ke konsumen memerlukan waktu beberapa hari.

Kendala lainnya berupa banyak warga yang belum paham akses dan mengoperasikan system digital, rata-rata pelaku usaha bukan dari kaum milenial yang seyogyanya perlu pendampingan khusus dari anggota masyarakat lainnya yang mengenal system digital.

\section{KESIMPULAN DAN SARAN}

Kesimpulan penelitian ini adalah pelaksanaan pelatihan marketplace bagi pelaku usaha kue di desa Jatiaragas sudah cukup baik. Namun terdapat kendala berupa terdapat produk yang cepat kadaluarsa yang akan menghambat distribusi barang dan kurangnya pemahaman pelaku usaha kue dalam mengenal system digital.

Saran untuk pelaku usaha kue, untuk pemasaran online setidak nya produk kue waktu kadaluarsanya diusahakan minimal 1 minggu. Sedangkan bagi kaum milenial yang paham sistem digital dapat membantu para pelaku usaha dalam memasarkan produknya di marketplace. 


\section{Daftar Pustaka}

Basu Swastha, D., \& Irawan. (2003). Manajemen Pemasaran Modern . Yogyakarta: Liberty.

Handayani, M. (2017). Analisis Beberapa Variabel yang Mempengaruhi Keputusan Pembelian Konsumen E-Commerce.

Rivai, Veithzal dan Ella Jauvani Sagala. 2011. Manajemen Sumber Daya Manusia untuk perusahaan dari teori ke praktik. Jakarta: Rajawali Pers

Tjiptono, F. (2002). Strategi Pemasaran (Keenam ed.). Yogyakarta: ANDI OFSSET. 